\title{
PREDICTION OF FINANCIAL DISTRESS: CASE OF MINING ENTERPRISES IN CZECH REPUBLIC
}

\author{
Zuzana Rowland ${ }^{1, a, *}$, Alla Kasych ${ }^{2, b}$ and Petr Suler ${ }^{3, \mathrm{c}}$ \\ ${ }^{1}$ School of Expertness and Valuation. Institute of Technology and Business in Ceske Budejovice. \\ Okruzni 517/10, 37001 Ceske Budejovice, Czech Republic \\ ${ }^{2}$ Department of Management and Public Administration. Kyiv National University of Technologies \\ and Design. 2 Nemirovich-Danchenko Street, 01011 Kyiv, Ukraine \\ ${ }^{3}$ School of Expertness and Valuation. Institute of Technology and Business in Ceske Budejovice. \\ Okruzni 517/10, 37001 Ceske Budejovice, Czech Republic \\ arowland@mail.vstecb.cz, ${ }^{b} k a s i c h . a l l a @ g m a i l . c o m, ~{ }^{c}$ petr.suler@cez.cz \\ ${ }^{*}$ Corresponding author
}

Cite as: Rowland, Z., Kasych, A., Suler, P. (2021). Prediction of financial distress: Case of mining enterprises in Czech Republic, Ekonomicko-manazerske spektrum, 15(1), 1-14.

Available at: dx.doi.org/10.26552/ems.2021.1.1-14

Received: 6 October 2020; Received in revised form: 27 January 2021; Accepted: 8 February 2021; Available online: 25 February 2021

\begin{abstract}
The ability to predict a company's financial health is a challenge for many researchers and scientists. It is also a distracting topic, as many other new approaches to financial health predictions have emerged in recent years. In this paper, we focused on identifying the financial health of mining companies in the Czech Republic. We chose the neural network method because, based on various instances of related research, neural networks represent a more reliable financial forecast than mathematical-statistical methods such as discriminant analysis and logistic regression. The concept of a neural network emerged with the first artificial neural networks, inspired by biological systems. The existence of prediction and classification problems directly predetermines artificial neural networks with respect to a given issue. We used the Amadeus database for processing, including financial indicators, SPSS, and Visual Gene Developer software. In total, we analyzed sixty-four mining companies. Complete data on financial stability were available for fifty-three companies, which we explored, and based on these results, identified financial situations for the other thirteen. Based on the available information, we processed a neural network and regression analysis. We managed to classify thirteen companies as solvent, insolvent, and in the grey zone, with the help of prediction.
\end{abstract}

Keywords: neural network; financial prediction; mining; solvency; bankrupt

JEL Classification: C5; C53

\section{Introduction}

The extractive industry occupies a unique position among sectors, as its activity provides raw materials for other industries, giving it a position at the very origin of this chain of industries. No extractive industry can be characterized only in terms of economic inputs and outputs, because it requires significant investment inputs and produces outcomes with low added value. It serves primarily as a supporting type of sector for other downstream industries. The primary task of the mining industry includes securing the raw material base. It is naturally 
also necessary to mention the production of minerals for the market (mining and processing of minerals), and transport from producer to consumer. At the same time, it is securing raw materials from foreign sources, and consumption of minerals.

In present day market economy conditions, we consider financial management an integral part of a company's economic activity. Its main task is to manage financial processes. Financial management covers five essential areas-financial planning, financial decision-making, organization of financial procedures, financial control, and financial analysis.

Financial analysis assesses a company's economic situation and achievement of financial goals for the past period, in which case we talk about ex-post financial analysis, while analysis which predicts and evaluates future development of the company's economic situation is referred to as ex-ante financial analysis, with its particular methods (Gundova, 2015).

Ex post analysis identifies the present and the past. The main disadvantage of the mentioned method is the that the company cannot in any way influence or change the already achieved state. Therefore, it is crucial to identify potential risks or problems, and eliminate them, in time. Such early identification of "emerging" problems is made possible by ex-ante financial analysis, which we also refer to as an early warning systems. The risk associated with the business is closely related to the opportunities that arise for the company. Frequently, opportunity/risk is associated with change and innovation. In managing innovation, it is essential to know the incentives or factors that, in many cases, provide the fundamental drivers of earnings, competitive advantages, and the sustainable growth of measures of their effectiveness (Durana et al., 2020). Earnings management is one of the most challenging, debated, and controversial topics in finance and financial management. Organizational, legislative, and societal norms related to earnings management ethics can vary widely, with top management and the economic environment playing an essential role in shaping corporate societal norms (Kliestik et al., 2020; Siekelova et al., 2020). A view and approach to profit is an integral part of corporate finance and a symbol of any healthy economy (Valaskova et al., 2020).

Ex-ante financial analysis is a relatively new discipline in financial management, having originated in the 1980s, as an attempt to predict companys' financial situation and prevent threats that would lead to economic collapse.

Ex-ante analysis includes the so-called predictive methods of financial accounting, through which negative indicators can be identified, and future developments can be predicted. Information sources for predicting a company's future situation can be, e.g., financial statements, data on current and future cash flows and their analysis, and external knowledge that can be acquired in the financial market (Gundova, 2015). The first model of bankruptcy prediction was introduced by Altman (1968), known as the Almant Z-Score. This model has been widely used and is still relevant for assessment of a company, i.e. whether it is bankrupt, in the grey zone, or healthy. The models have categorized companys as either healthy, in the grey area, or bankrupt, based on different scores (Jayasekara, 2020).

After the 1970s, several other models for predicting bankruptcy were introduced, such as Springate (1978); Ohlson (1980); Zmijewski (1983); and Grover and Lavin (2001). The titles of the models were based on the names of the scientists who introduced them. In their study, Jayasekera et al. (2020) identified four models of bankruptcy prediction, namely: mathematical, neural network, statistics, and market models. Meanwhile, Wu et al. (2010) categorized bankruptcy models into the discriminatory model popularized by Altman in 1968, the logistic model introduced by Ohson in 1980, the probit model developed by Zmijewski in 1984, the hazard model proposed by Shumway (2001), and the Black-Scholes-Merton (BSM) probability model, introduced by Hillegeist et al. (2004). 
Since the estimation of the pioneering model of multivariate discriminant analysis by Altman, numerous research studies have been carried out with the use of a wide variety of statistical methods, e.g., Alaka et al. (2018); Bandyopadhyay (2006); Barboza et al. (2017); Delen et al. (2013); Kliestik et al. (2020); Giannopoulos and Sigbjornsen (2019); Durica et al. (2019); Kovacova et al. (2019); Svabova et al. (2018); Ho et al. (2013); Hosmer et al. (2013); Jackson and Wood (2013); Kieschnick et al. (2013); Kumar and Ravi (2007); Laitinen (2007); Lukason and Hoffman (2014); Lyandres and Zhdanov (2013); Mihalovic (2016); Orsenigo and Vercellis (2013); Psillaki et al. (2010). Balcaen and Ooghe (2006) noted the most popular statistical techniques are multivariate discriminant analysis and logistic regression models.

A similar issue was addressed by Syamni et al. (2018) in their work "Bankruptcy Prediction Models and Stock Prices of the Coal Mining Industry in Indonesia", by empirically investigating the usefulness of Olhson's, Almant's, Grover's, Springate's and Zmijew's models to predict bankruptcy of nineteen coal mining companies. It also attempted to measure the effects of these bankruptcy prediction models' scores on the share prices of coal mining companies in Indonesia. The analysis technique used in the research was panel regression. Their study showed that the bankruptcy prediction scores of the Ohlson and Almant modifications were considered the dominant prediction models that affected the share prices of coal companies in Indonesia. They suggested that the bankruptcy prediction model could be used to measure stock price movements and coal mining companies' performance in the country.

According to an article by Abrahamsson et al. (2009), the global metal industry faces many challenges that need to be addressed through a socio-technical approach covering the whole chain of mining and adding value to minerals, including environmental issues. As a result, significant structural rationalization can be expected, with strong companies being able to afford to invest in the future while weak companies will run out of capital. The general effect is that all mining companies are under increased pressure for further rationalization, which requires new technologies and new organizational solutions and conditions. At the same time, however, it is necessary to monitor this development and predict possible results.

The methodology of predictive financial analysis is continually evolving, as evidenced by the fact that significant steps have been taken in recent years at the level of mathematical and statistical methods. However, the results of research in the field of artificial intelligence represent a new challenge for economists, which is because neural networks represent a more reliable financial forecast compared to mathematical-statistical methods such as discriminant analysis and logistic regression.

Table 1: Bankrupt models used for prediction financial health of mining companies

\begin{tabular}{lll}
\hline Utilized model: & Formula: & Score \\
& & \\
& $S S=1.03 X 1+3.07 X 2+0.66 X 3+0.4 X 4$ & \\
& $\mathrm{X} 1=$ working capital/total assets & SS $>0.862=$ healthy \\
Springate, 1978 & $\mathrm{X} 2=$ net profit before interest taxes/total assets & SS $<0.862=$ bankrupt \\
& $\mathrm{X} 3=$ net profit before taxes/current liabilities & \\
& $\mathrm{X} 4=$ sales/total assets
\end{tabular}




\begin{tabular}{|c|c|c|}
\hline Utilized model: & Formula: & Score \\
\hline Ohlson, 1980 & $\begin{array}{l}O S=-1.32-0.407 X 1+6.03 X 2-1.43 X 3+0.0757 X 4-2.37 X 5- \\
1.83 X 6+0.285 X 7-1.72 X 8-0.521 X 9 \\
X 1=\text { Log (total assets/GNP index) } \\
\text { X2 = Total liabilities/total assets } \\
\text { X3 = Working capital/total assets } \\
\text { X4 = Current liabilities/current assets } \\
\text { X5 = } 1 \text { if total liabilities }>\text { total assets; } 0 \text { if otherwise } \\
\text { X6 = Net income/total assets } \\
\text { X7 = Cash flow from operations/total liabilities } \\
\text { X8 = } 1 \text { if Net income negative } ; 0 \text { if otherwise X9 }=(\text { NIt }- \text { NIt-1) } / \\
(\text { NIt }+ \text { NIt-1) }\end{array}$ & $\begin{array}{l}\text { OS }<0.38=\text { healthy } \\
\text { OS }=0.38=\text { grey area } \\
\text { OS }>0.38=\text { bankrupt }\end{array}$ \\
\hline
\end{tabular}

$\begin{array}{lll} & \boldsymbol{Z}=\mathbf{- 4 . 3 - 4 . 5} \boldsymbol{X} \mathbf{1}+\mathbf{5 . 7} \mathbf{X} \mathbf{2}-\mathbf{0 . 0 0 4 X 3} & \text { ZS }<0=\text { healthy } \\ \text { Zmijewski, } & \text { X1 }=\text { ROA (Net income/ total assets) } & \text { ZS }>0=\text { bankrupt } \\ 1983 & \text { X2 = Leverage (Total liabilities/total assets) } & \\ & \text { X3 }=\text { Liquidity (Current assets/current liabilities) } & \end{array}$

$\begin{array}{lll} & G=1.650 X 1+3.404 X 2-0.016 R O A+0.057 & \text { GS } \geq 0.01=\text { healthy } \\ \text { Grover, } 2001 & \text { X1 }=\text { Working capital/Total assets } & \text { GS } \leq-0.02=\text { bankrupt }\end{array}$

$\mathrm{X} 2=$ Earnings before interest and taxes/Total assets

Modified

Altman

Z-Score, 1995

\section{Altman, Z-score, 1967}

$\begin{array}{ll} & \text { IN95 }=V 1 X 1+0.11 X 2+V 3 X 3+V 4 X 4+0.10 X 5+V 6 X 6 \\ & X 1=\text { Total Asset/Liabilities } \\ \text { Neumaiers, } & \text { X2 = Earnings before interest and taxes /Expences } \\ \text { IN95, } 1995 & \text { X3 = Earnings before interest and taxes /Total Asset } \\ & \text { X4 }=\text { Total Revenues/Total Assets } \\ & \text { X5 }=\text { Current Assets/Current Liabilities } \\ & \text { X6 }=\text { Liabilities over due date/Total Revenue }\end{array}$

$\mathrm{ZM}>2.60=$ healthy $\mathrm{ZM}=1.10-2.60=$ grey $\mathrm{ZM}<1.10=$ bankrupt

$Z>2.9=$ healthy $\mathrm{Z}<2.9=$ bankrupt IN95 $>2.00=$ healthy $1<\mathrm{IN} 95 \leq 2$ =grey zone IN95 $\leq 1$ = bankrupt

Source: authors compilation

Odom and Sharda (1990) were the first to use neural networks based on evolutionary algorithms in their predictions. The concept of a neural network emerged historically when biological systems inspired the first artificial neural networks. There are several definitions of a neural network. Nevertheless, its main feature is always its structure, namely that of neurons with interconnections over which signals propagate. Above this structure, a learning algorithm is usually implemented, which adjusts the weights on the connections according to the samples given to the neural network's input to fulfill some desired goal. Interestingly, this feature 
involves many systems, and yet all can be described by the same structure. Several learning algorithms can work successfully with such different forms.

It is undoubtedly crucial to address this issue, as interest in financial health should be central to every business, and it is necessary to monitor and analyze the effects of change on its development. Therefore, it is possible to consider the issue as one of the hot topics as more and more models are emerging to estimate companies' financial health. In this paper, however, we have focused on neural networks. They have recently proven themselves and are considered by many authors to be the best prediction tool in this area, being currently widely implement in almost every field due to their accuracy, which includes financial prediction. During the production of this article, we nevertheless analyzed seeveral renowned databases and can state that neural networks do not seem to have been used for prediction of financial health of mining companies so far. Such companies have been studied by various bankruptcy models, as listed in Table 1 above, by multiple authors, which was also the reason for choosing this topic to expand the publication awareness of financial development using neural networks in the mining industry.

Determining corporate risk failure using financial statements has been one of the most exciting topics for investors and decision-makers. Discriminatory variables that can be chosen to predict firms' health significantly affect the models' accuracy, mostly when missing data are available. Therefore, the authors Azayite and Achchab (2016), in their publication, developed a hybrid model of neural networks to study the risk of failure of Moroccan companies concerning the availability and reliability of data. This methodology combines discriminant analysis, a multilayer neural network, and self-organizing maps based on their three-stage analysis. Similarly, the study by Mai et al. (2019) presents deep learning models for predicting corporate bankruptcies using text publications. Although textual data is standard, it is infrequently considered in financial choice support models. Deep learning uses layers of neural networks to extract elements from textual information for prediction.

Bankruptcy prediction is always a thematic issue. All business entities' activities are directly or indirectly influenced by various external and internal circumstances that can affect a company in insolvency and lead to bankruptcy. It is crucial to find a suitable tool to evaluate any company's future evolution in the market. The aim of the paper by Horak et al. (2020) is to create a model for predicting companies' potential bankruptcy using appropriate classification methods, namely support-vector machines and artificial neural networks, and to estimate the results of the methods used. Chung et al. (2016), in their publication, also addressed companies' financial situations. The companies were located in Taiwan and the study noted that the volume of outstanding corporate debt in the country was on the rise. Companies facing financial distress reveal many relevant signs related to their financial data. The study assumes this provides managers and investors with a reference for decision-making through a systematic approach, as they can look for signs of companies facing financial hardship. In their paper, a new prediction system is proposed based on an intelligent classification to distinguish bankruptcy predictions. This method is called the cerebellar neural network model. It uses an artificial neural network, genetic programming, and the proposed CMNN to construct predictive models of financial distress and compare performance.

\section{Methodology}

Predicting a company's financial health is very important for companies to avoid financial loss; they must assess their financial risk before making a decision. Financial difficulties are not the same as bankruptcy. The first case occurs when a company cannot meet its financial 


\section{Prediction of financial distress: Case of mining enterprises in the Czech Republic}

Authors: Zuzana Rowland, Alla Kasych, Petr Suler

obligations due to a decline in its activities and high costs. In contrast, the second is the extreme situation in which corporations cease trading due to financial distress. The ability to predict a company's financial future is essential, as testified by the vast number of models for doing so that have emerged in recent decades. When preparing this article, we opted for the artificial neural networks technique, which we assessed as one of the best methods available.

We decided to apply neural networks to a specific sector to achieve the most accurate results, namely that of mining companies in the Czech Republic with a turnover of more than ten million euros. A total of sixty-four companies were analyzed. The data was obtained from the AMADEUS database which contains financial information on European companies and provides comparable data for search and analysis. For fifty-one of the companies, information was provided on whether the company in question was financially stable or not. For the other thirteen companies, it was not clear to which category they belonged, so we decided to identify their financial health. We started from the three ratio variables entered into the Visual Gene Developer software.

Input 1 = working capital / total assets;

Input $2=$ net income $/$ total assets;

Input 3 = cash flow / total liabilities.

We focused on these variables, as they reflect to some extent each company's financial condition and the availability of data from the Amadeus database.

The IBM-developed SPSS statistical-mathematical software was used to process the data using the neural network method. Besides, Visual Gene Developer was used for graphical demonstration (see Figure 1). As specified in the software, there were three input variables and one output variable. Hidden layers were set to two, and in the first and second levels, the number of nodes was further specified, as ten nodes ion the first level, and five nodes on the second level. Subsequently, the determined data needed for training and prediction was entered, and we started the training process, allowing it to run until the sum of errors reached much less than three. The total number of cycles reached 31,020 and the whole learning process took two minutes and nineteen seconds. 
Figure 1: Visual Gene Developer-configuration of Neural Network: Case of Mining Companies of Czech Republic

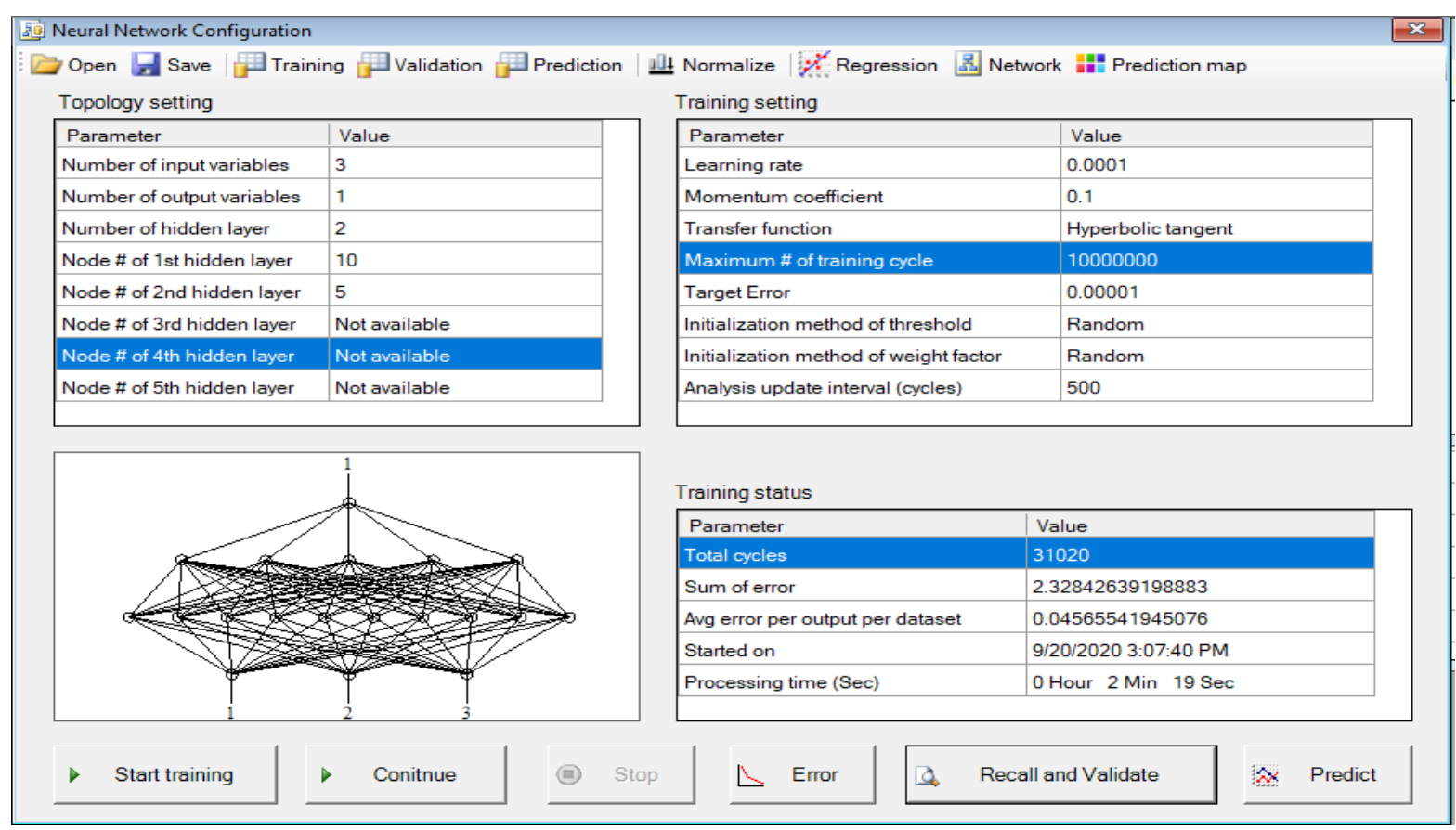

Source: authors compilation

The software provides general gene analysis and optimization features along with an interactive, user-friendly interface. It also includes unique features such as programming capabilities, dedicated mRNA secondary structure prediction, artificial neural network modeling, network and multithreaded computations, and user-friendly programming modules. The software allows the user to analyze and optimize the sequence using main menu functions or specialized module windows (Jung and McDonald, 2011).

The artificial neural network model can be defined as a nonlinear computational model that consists of many highly interconnected artificial neurons to simulate biological neural networks' structure and function. The goal is to map a set of input patterns to a corresponding location of output patterns. It has been widely used to model complicated nonlinear systems that consist of several variables to predict data patterns. Due to the potential application of artificial neural network models for gene analysis and optimization, Visual Gene Developer includes a set of tools for artificial neural network prediction (Jung \& McDonald, 2011).

The software consists of several functional modules, as shown in Figure 2, and most of the algorithms have been compressed into classes. For simplicity, a class can be defined as a reproducible programming object containing a collection of functions to provide a programming environment like Mathematica ${ }^{\mathrm{TM}}$ or Matlab ${ }^{\mathrm{TM}}$. 
Figure 2: Visual Gene Developer - software architecture; Jung and McDonald (2011)

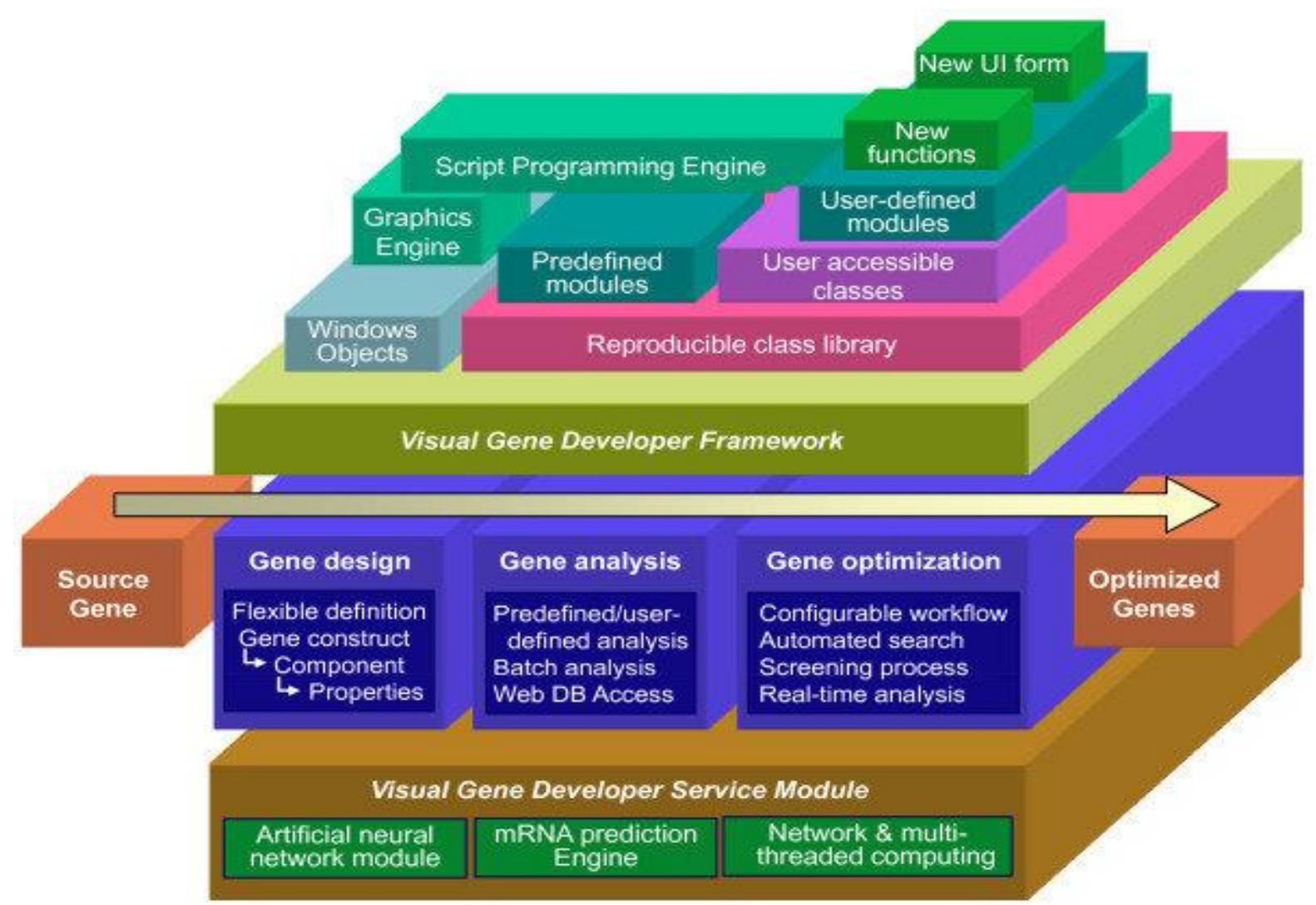

Source: authors compilation

Visual Gene Developer includes a set of tools for predicting an artificial neural network. The software has a configuration window for designing the topology and adjusting the learning parameters. It can directly import (or export) a set of data from the clipboard or typical ASCII text files. A specific forward neural network with a standard back-propagation learning algorithm for network training has been implemented (Liu et al., 2020).

As with other classes, Visual Gene Developer provides programmatic access to a suite of tools and neural network classes, which means that ANN models can be used to develop new modules, for example, to predict gene expression levels of gene constructs in real-time during the gene optimization process if the user has already developed and trained neural networks to correlate several different parameters with expression levels. The software also includes useful features for analyzing a trained neural network map and testing input and output variables such as 2-D or ternary diagrams (Jung and McDonald, 2011).

\section{Results}

In total, we were able to obtain the necessary data for fifty-one of the companies from the Amadeus database, and this data served as inputs and outputs to neural networks. At the same time, we analyzed the prediction of financial health for the remaning thirteen companies in the same industry based on already analyzed data. 

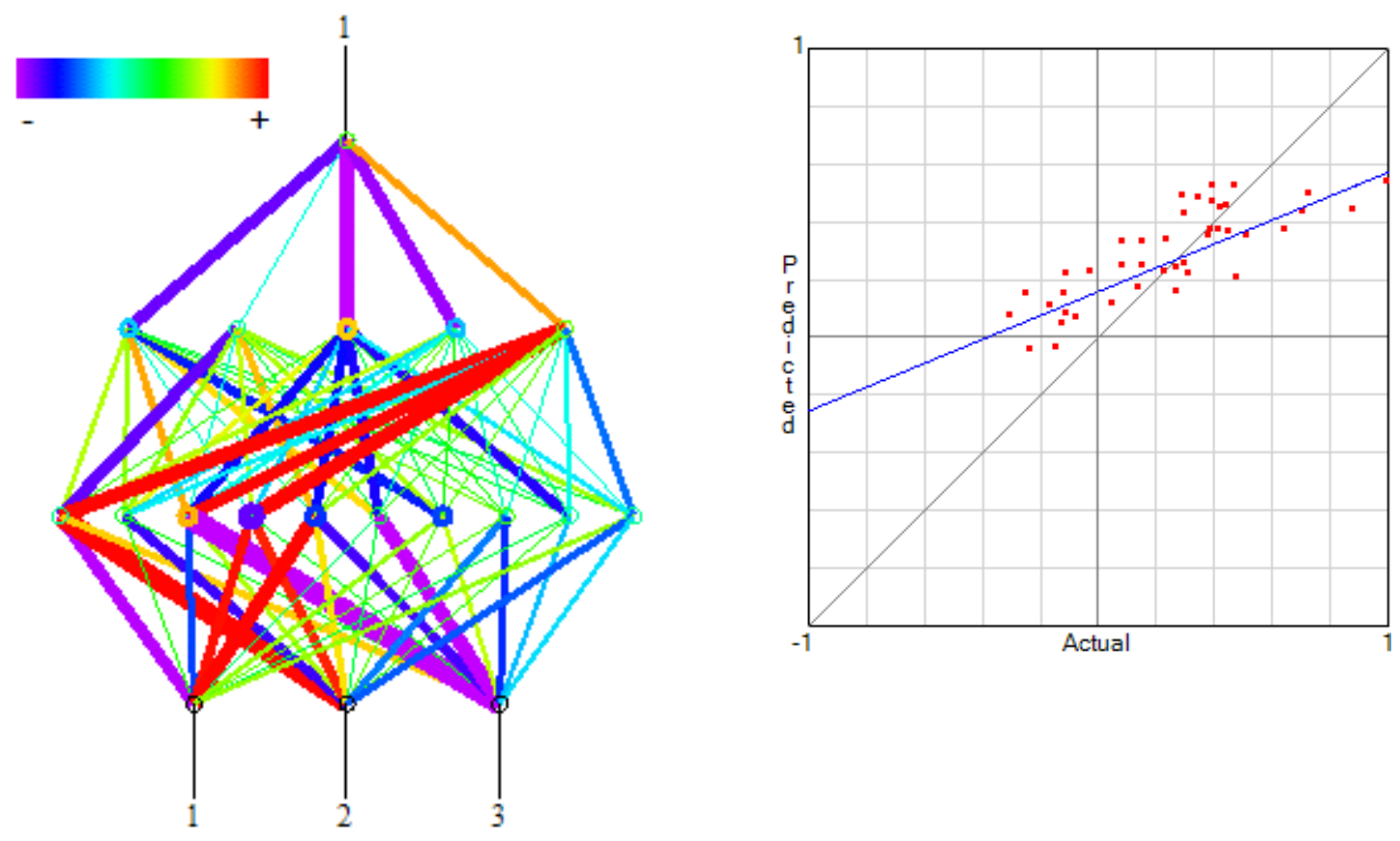

Source: authors compilation

Figure 3 shows a neural network along with regression analysis. The 'Neural Network Map Analysis' displays weighting factors and network thresholds such as color and latitude. The final neural network in Figure 3 represents a graphical visualization of the trained network, and it is possible to check the color and width of the lines or circles. Lines represent weighting factors and circles indicate thresholds. Red color corresponds to a high positive number in the diagram, while purple color stands for a high negative number. The width of the line is proportional to the absolute value of the weighting factor or threshold. After the learning process ended, it was possible to generate a regression analysis. When we look at Figure 3, we can see a regression function on the right, where the individual exit points stick to the lines.

The Visual Gene Developer software also includes a pattern analysis function in the artificial neural network model. Figure 4 shows a ternary plot to test three input variables. Figure 5 shows a plot with two inputs. Figure 4 shows that the total classification by output - solvency is affected by three inputs, each of them having a different effect on the output. We can see that one of the three inputs is in intense red and very well defined - it is characterized by a high positive number and, conversely, the purple color for one of the inputs marks a negative value. The component system is set in three variables, and it is possible to change the sequence of individual inputs and investigate changes. The default value of all inputs is configurated at zero. The answers associated with the proportions of the component variables in the ternary graph, which represent the inputs affecting the mining companies' financial health, are plotted on a three-dimensional display for each level of the cluster variable. One component graph is created for each level of the grouping variable, and all component graphs are arranged in one display to allow comparison between inputs.

Neural networks use inputs to produce outputs. In this case, we opted for three inputs. These were ratios: input $1=$ working capital/total assets; input $2=$ net income/total assets; input $3=$ cash flow/total liabilities. The output value represented solvency, insolvency, or grey zone for the given company. For fifty-one of the analyzed companies, results on financial health were available. This information was lacking for the remaining thirteen, and we therefore decided to 
produce a prediction. The decisive factor was the positive or negative output, which placed the company in the appropriate category.

Figure 4: Pattern analysis with 3 inputs

\begin{tabular}{l|l} 
Parameter & Value \\
\hline Component system & 3 variables system \\
\hline First input variable & 1 \\
\hline Second input variable & 2 \\
\hline Third input variable & 3 \\
\hline Target output variable & 1 \\
\hline Default value of Input 1 & 0 \\
\hline Default value of Input 2 & 0 \\
\hline Default value of Input 3 & 0 \\
\hline Sum of 3 input variables & 1 \\
\hline Color spectrum & 2 \\
\hline Color spectrum adjustment & 1 \\
\hline Calculation interval & 3 \\
\hline
\end{tabular}

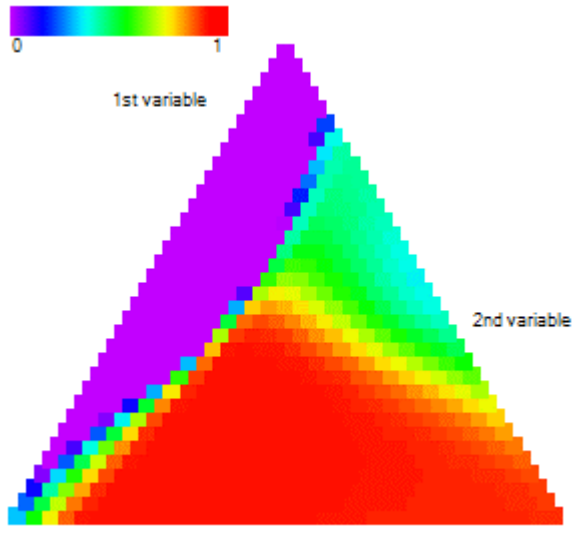

3rd variable

Source: Authors compilation

Figure 5: Pattern analysis with 2 inputs

\begin{tabular}{l|l} 
Parameter & Value \\
\hline Component system & 2 variables system \\
\hline First input variable & 1 \\
\hline Second input variable & 2 \\
\hline Target output variable & 1 \\
\hline Default value of Input 1 & 0 \\
\hline Default value of Input 2 & 0 \\
\hline Default value of Input 3 & 0 \\
\hline Color spectrum & 2 \\
\hline Color spectrum adjustment & 1 \\
\hline Calculation interval & 3
\end{tabular}

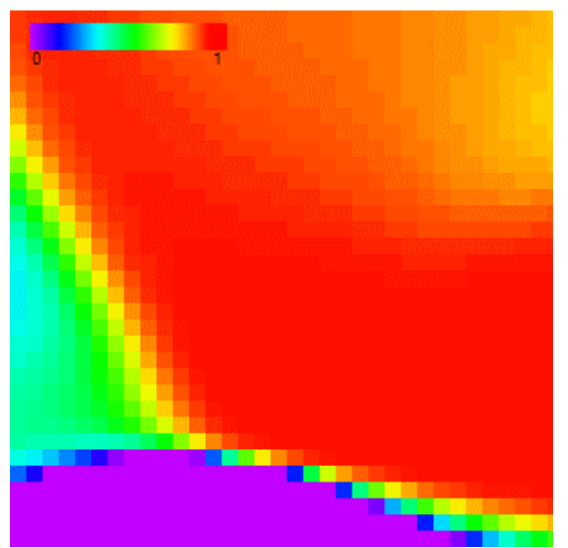

Source: author's compilation

A total of sixty-four mining companies in the Czech Republic were analyzed. These can be divided into two groups. In the first group, there were fifty-one companies, about which we had complete information with regard whether they were solvent or not. Specifically, thirty-six companies were classified as solvent, another six were included in the grey zone, and nine were classified as bankrupt. Neural networks analyzed the second group of thirteem companies engaged in activities in the mining industry. Four of them were subsequently classified as insolvent or in danger of bankruptcy. The other two showed values typical for the grey zone, and the remaining seven were solvent.

Based on the importance score of the SPSS analysis, we analyzed the independent variable importance. We identified that the essential aspect is input 2 , followed by input 1 , and finally input 3. 


\section{Discussion}

The goal of neural networks is to reach a decision based on a certain amount of input information. This primary mode "to provide inputs, and then advise how to decide" is something neural networks have in common with other types of data mining algorithms such as decision trees, regression, or support-vector machines. The important dividing line is that for now, each of the machine learning procedures requires a list of criteria based on which one wants to make a decision. Neural networks will only ask for rough facts, and will produce the decision factors themselves. Neural networks can derive decision factors without having to name them. While they are also criticized for their approximation properties and long-term learning, they still find application in almost all spheres.

These systems are probably the future. The goal of artificial intelligence systems is to develop algorithms that allow machines to solve tasks that a person can only solve with respective knowledge. All such systems should store knowledge, apply it to solving problemsthinking, and gain new understanding during experiments-learning.

There are several studies that address similar issues. Financial difficulties have big impact on companies. Over the last four decades, predicting corporate bankruptcy and economic hardship has become a significant concern for various corporate stakeholders. Salehi et al. (2016) aimed to predict Iranian companies' financial difficulties using four different techniques. By comparing the performances of the models, it was concluded that artificial neural networks outperform other methods. Chen and Du (2009) used an artificial neural network and data mining techniques to create a model of financial distress prediction. Their experiment with a total of thirty-seven ratios and sixty-eight listed companies as initial samples yielded a satisfactory result, which testifies to the feasibility and validity of these methods for predicting companies' financial distress. According to Mselmi et al. (2017), prediction of financial distress is a central problem of empirical finance. They found that empirical results suggest that one year before a financial crisis, a support-vector machine is the best classifier with an overall accuracy of $88.57 \%$. Meanwhile, two years before financial crisis, the hybrid model surpasses support-vector machines, the Logit model, the partial least squares, and artificial neural networks, with an overall accuracy of $94.28 \%$. The issue of predicting financial vulnerability for construction contractors was addressed by Choi et al. (2018). They managed to design a model predicting the suppliers' financial difficulties for two and three years before the forecast point using the financial definition of financial distress. This model can predict contractors' financial problems with great accuracy, from the initial stages of construction to the final phase, to help project owners and broad stakeholders related damages. To verify the predictive power of network-based variables and the gradient enhancement method based on the GA genetic algorithm predicting financial distress, Liu et al. (2019) used an empirical study based on real data from Chinese listed companies. Their results suggest that the introduction of network variables and the GA-based gradient enhancement method for predicting financial distress can increase predictive performance in terms of accuracy. To predict financial distress, with its impact on companies' sustainability and growth, Rafatnia et al. (2020) used logistic regression and decision trees. They found that profitability, liquidity, leverage, interest rates, cash flow, growth, and GDP were statistically significant in distinguishing companies in need from companies in demand in different sectors. In the past, especially in times of financial crisis, many researchers and practitioners have been developing models that can predict financial failure. The study by Raza et al. (2020) conducted an unsystematic review of the development of different models related to financial distress and found out which models, techniques, and factors (variables) were taken into account. 
Their results and suggestions are mentioned in the introduction section. The topic is very current, and many scientists continue to focus on investigating it further. The present article could be of use for authors creating scientific publications, or serves as a model example at universities or for other analyzes.

\section{Conclusion}

As part of this research paper, we addressed the issue of neural networks and their use to predict companies' financial health in the mining industry.

The history of artificial neural networks dates back to 1943. The beginnings of neural networks were not entirely straightforward, many authors tried to create the best possible learning procedure, but without success, and interest in neural networks was not renewed until 1982. John Hopfield (1988), presented a two-way network; until then, the connections between neurons were only one-way. In the same year, Reilly et al. (1988) used a hybrid network, a multi-layer network, with each layer having a different problem-solving strategy. With multilayer network development, it was necessary to apply the Widrow-Hoff rule on error distribution on multiple layers. Simultaneously, three independent teams succeeded. The backpropagation algorithm was created from the results of this research. The name is derived from the algorithm's operation, where the individual neurons' errors are distributed over the network in the direction from output to input. Hybrid systems used only two layers; there are usually more of them when using the backpropagation algorithm. The result is an extension of the learning time, which can exceed several thousand iterations.

Many learning algorithms and various architectures were introduced, and in the 1990s, the computational universality of artificial neural networks was proved. The forward neural network with a window to the past and recurrent neural networks with internal memory can represent the data's time context. They learn very slowly, and we need thousands of repetitions to train them well.

The neural network is currently the most reliable method used in almost every industry. This fact was the reason for selecting the financial analysis of companies' health in the Czech Republic's mining industry. This industry and its financial stability have been verified using various bankruptcy models, but neural networks have not yet been used, so we decided to analyze and predict using this method. An IBM-developed software, SPSS, was chosen for the analysis. Besides, the Visual Gene Developer program was used, the outputs of which are graphically illustrated in this research paper. At the same time, it was possible to predict the development of thirteen companies for which the solvency results were not known. From the obtained research results, it can be stated that neural networks have an excellent ability to generalize the process and appear to be a suitable tool for monitoring mining companies' financial health. The designed and tested network model with a topology of 3-10-1 to predict financial health achieved a good result, especially in the training set, where the average percentage of error was $2.33 \%$ in the processing time of two minutes and nineteen seconds. For a reliable prediction of financial health, more experimental data are needed to improve the neural network training.

\section{References}

Abrahamsson, L., Johansson, B., \& Johansson, J. (2009). Future of metal mining: Sixteen predictions. International Journal of Mining and Mineral Engineering, 1(3), 304-312.

Alaka, H. A., Oyedele, L. O., Owolabi, H. A., Kumar, V., Ajayi, S. O., Akinade, O. O., \& Bilal, M. (2018). Systematic review of bankruptcy prediction models: Towards a framework for tool selection. Expert Systems with Applications, 94, 164-184. 
Altman, E. I. (1968). Financial ratios, discriminant analysis and the prediction of corporate bankruptcy. The Journal of Finance, 23(4), 589-609.

Azayite, F. Z., \& Achchab, S. (2016). Hybrid discriminant neural networks for bankruptcy prediction and risk scoring. Procedia Computer Science, 83, 670-674.

Bandyopadhyay, A. (2006). Predicting probability of default of Indian corporate bonds: Logistic and Z-score model approaches. The Journal of Risk Finance.

Barboza, F., Kimura, H., \& Altman, E. (2017). Machine learning models and bankruptcy prediction. Expert Systems with Applications, 83, 405-417.

Delen, D., Cemil K., \& Ali U. (2013). Measuring firm performance using financial ratios: A decision tree approach. Expert Systems with Applications, 40, 3970-83.

Durana, P., Zauskova, A., Vagner, L., \& Zadnanova, S. (2020). Earnings drivers of slovak manufacturers: Efficiency assessment of innovation management. Applied Sciences, 10(12), 4251.

Durica, M., Podhorska, I., \& Durana, P. (2019). Business failure prediction using cart-based model: A case of Slovak companies. Ekonomicko-manazerske spektrum, 13(1), 51-61.

Giannopoulos, G., \& Sigbjornsen, S. (2019). Prediction of bankruptcy using financial ratios in the Greek market. Theoretical Economics Letters, 9, 1114-1128.

Grover, J., \& Lavin, A. (2001). Financial ratios, discriminant analysis and the prediction of corporate bankruptcy: a service industry extension of Altman's z-score model of bankruptcy prediction. Southern Finance Association.

Gundova, P. (2015). Prediction methods of financial situation in Czech companies in globalisation. Globalization and Its Socio-Economic Consequences, 7, 163.

Ho, C. Y., McCarthy, P., Yang, Y., \& Ye, X. (2013). Bankruptcy in the pulp and paper industry: Market's reaction and prediction. Empirical Economics, 45(3), 1205-1232.

Hopfield, J. J. (1988). Artificial neural networks. IEEE Circuits and Devices Magazine, 4(5), 3-10.

Horak, J., Vrbka, J., \& Suler, P. (2020). Support vector machine methods and artificial neural networks used for the development of bankruptcy prediction models and their comparison. Journal of Risk and Financial Management, 13(3), 60.

Hosmer Jr, D. W., Lemeshow, S., \& Sturdivant, R. X. (2013). Applied Logistic Regression (Vol. 398). John Wiley $\&$ Sons.

Chen, W. S., \& Du, Y. K. (2009). Using neural networks and data mining techniques for the financial distress prediction model. Expert Systems with Applications, 36(2), 4075-4086.

Choi, H., Son, H., \& Kim, C. (2018). Predicting financial distress of contractors in the construction industry using ensemble learning. Expert Systems with Applications, 110, 1-10.

Chung, C. C., Chen, T. S., Lin, L. H., Lin, Y. C., \& Lin, C. M. (2016). Bankruptcy prediction using cerebellar model neural networks. International Journal of Fuzzy Systems, 18(2), 160-167.

Jackson, R. H., \& Wood, A. (2013). The performance of insolvency prediction and credit risk models in the UK: A comparative study. The British Accounting Review, 45(3), 183-202.

Jayasekara, S. S. D., Perera, K. W., \& Ajward, R. (2020). Empirical studies on the performance of banks: A systematic literature review for future research. Journal of Research in Emerging Markets, 2(4), 1-20.

Jung, S. K., \& McDonald, K. (2011). Visual gene developer: a fully programmable bioinformatics software for synthetic gene optimization. Bmc Bioinformatics, 12(1), 340.

Kieschnick, R., La Plante, M., \& Rabih, M. (2013). Working capital management and shareholders' wealth. Review of Finance, 17, 1827-52.

Kliestik, T., Belas, J., Valaskova, K., Nica, E., \& Durana, P. (2020). Earnings management in V4 countries: The evidence of earnings smoothing and inflating. Economic Research-Ekonomska Istraživanja, 1-19.

Kliestik, T., Valaskova, K., Lazaroiu, G., Kovacova, M., \& Vrbka, J. (2020). Remaining financially healthy and competitive: The role of financial predictors. Journal of Competitiveness, 12(1), 74-92.

Kovacova, M., Kliestik, T., Valaskova, K., Durana, P., \& Juhaszova, Z. (2019). Systematic review of variables applied in bankruptcy prediction models of Visegrad group countries. Oeconomia Copernicana, 10(4), 743772.

Kumar, P. R., \& Ravi, V. (2007). Bankruptcy prediction in banks and firms via statistical and intelligent techniques-A review. European Journal of Operational Research, 180(1), 1-28.

Laitinen, E. K. (2007). Classification accuracy and correlation: LDA in failure prediction. European Journal of Operational Research, 183(1), 210-225.

Liu, J., Wu, C., \& Li, Y. (2019). Improving financial distress prediction using financial network-based information and ga-based gradient boosting method. Computational Economics, 53(2), 851-872.

Liu, J. Y., Zeng, L. H., \& Ren, Z. H. (2020). The application of spectroscopy technology in the monitoring of microalgae cells concentration. Applied Spectroscopy Reviews, 1-22. 


\section{Prediction of financial distress: Case of mining \\ enterprises in the Czech Republic \\ Authors: Zuzana Rowland, Alla Kasych, Petr Suler}

Lukason, O., \& Hoffman, R. C. (2014). Firm bankruptcy probability and causes: An integrated study. International Journal of Business and Management, 9(11), 80-91.

Lyandres, E., \& Zhdanov, A. (2013). Investment opportunities and bankruptcy prediction. Journal of Financial Markets, 16(3), 439-476.

Mai, F., Tian, S., Lee, C., \& Ma, L. (2019). Deep learning models for bankruptcy prediction using textual disclosures. European Journal of Operational Research, 274(2), 743-758.

Mihalovic, M. (2016). Performance comparison of multiple discriminant analysis and logit models in bankruptcy prediction. Economics \& Sociology, 9(4), 101.

Mselmi, N., Lahiani, A., \& Hamza, T. (2017). Financial distress prediction: The case of French small and mediumsized firms. International Review of Financial Analysis, 50, 67-80.

Odom, M. D., \& Sharda, R. (1990, June). A neural network model for bankruptcy prediction. International Joint Conference on neural networks, 163-168).

Ohlson, J. A. (1980). Financial ratios and the probabilistic prediction of bankruptcy. Journal of Accounting Research, 109-131.

Orsenigo, C., \& Vercellis, C. (2013). Linear versus nonlinear dimensionality reduction for banks' credit rating prediction. Knowledge-Based Systems, 47, 14-22.

Psillaki, M., Tsolas, I. E., \& Margaritis, D. (2010). Evaluation of credit risk based on firm performance. European Journal of Operational Research, 201(3), 873-881.

Rafatnia, A. A., Suresh, A., Ramakrishnan, L., Abdullah, D. F. B., Nodeh, F. M., \& Farajnezhad, M. (2020). Financial distress prediction across firms. Journal of Environmental Treatment Techniques, 8(2), 646-651.

Raza, H., Gillani, S. M. A. H., Ramakrishnan, S., Gillani, S. M. A. H., \& Imran, M. (2020). Nonsystematic review of financial sustainability and financial distress. International Journal of Psychosocial Rehabilitation, 24(06).

Reilly, D. L., Scofield, C. L., Cooper, L. N., \& Elbaum, C. (1988). Gensep: A multiple neural network learning system with modifiable network topology. First Annual International Neural Network Society Meeting.

Salehi, M., Shiri, M. M., \& Pasikhani, M. B. (2016). Predicting corporate financial distress using data mining techniques. International. Journal of Law and Management.

Shumway, T. (2001). Forecasting bankruptcy more accurately: A simple hazard model. The Journal of Business, $74(1), 101-124$.

Siekelova, A., Androniceanu, A., Durana P., \& Frajtova Michalikova, K. (2020). Earnings management (EM), initiatives and company size: An empirical study. Acta Polytechnica Hungarica, 17(9), 41-56.

Springate, G. L. (1978). Predicting the possibility of failure in a Canadian firm: A discriminant analysis (Doctoral dissertation, Simon Fraser University.).

Svabova, L., Kramarova, K., \& Durica, M. (2018). Prediction model of firm's financial distress. Ekonomickomanazerske spektrum, 12(1).

Syamni, G., Majid, M. S. A., \& Siregar, W. V. (2018). Bankruptcy prediction models and stock prices of the coal mining industry in Indonesia. Etikonomi, 17(1), 57-68.

Valaskova, K., Gavurova, B., Durana, P., \& Kovacova, M. (2020). Alter ego only four times? the case study of business profits in the Visegrad Group. E\&M Economics and Management, 23(3), 101-119.

Zmijewski, M. (1983). Predicting corporate bankruptcy: An empirical comparison of the extant financial distress models. Document de Travail. State University of New York at Buffalo.

Wu, Y., Gaunt, C., \& Gray, S. (2010). A comparison of alternative bankruptcy prediction models. Journal of Contemporary Accounting \& Economics, 6(1), 34-45. 